\title{
Impacts of the COERR Writing Project on Cambodian Students' Attitudes and Writing Performance
}

\author{
Hum Chan*, Srun Sotith \\ COERR Language Skills Center, Battambang, Cambodia
}

Email address:

chanhum_ubb@yahoo.com (H. Chan)

*Corresponding author

\section{To cite this article:}

Hum Chan, Srun Sotith. Impacts of the COERR Writing Project on Cambodian Students' Attitudes and Writing Performance. International Journal of Language and Linguistics. Vol. 4, No. 3, 2016, pp. 133-140. doi: 10.11648/j.ijl1.20160403.17

Received: March 7, 2016; Accepted: March 15, 2016; Published: May 23, 2016

\begin{abstract}
This study aims to assess the impacts of the Catholic Office for Emergency, Relief and Refugees (COERR) Writing Project (COERRWP) on students' attitudes and their writing performance in correlation with age, gender and language proficiency. In the first stage, a study was conducted to assess 45 students' actual writing performance based on score analysis of their writing test through 2011 to 2014. In the second stage, a quantitative survey questionnaire was administered to a further 80 students from the initial cohort of intermediate, upper and advanced levels. The study found that the COERRWP was effective in improving macro performance such as paragraph or essay structures rather than micro performance or the accurate use of lexico-grammar.
\end{abstract}

Keywords: Impact, Writing Project, Attitude

\section{Introduction}

On January 2012, the Writing Project (WP) was introduced by the COERR Language Skills Center, the Catholic Office for Emergency, Relief and Refugee (COERR). The WP framework was grounded on the literatures of the writing process $[18,25,27,28]$. The literatures suggested that good writing must go through several writing steps. Hence, the COERRWP, focused on helping students gain confidence in writing through the institutionalizing of the following six steps: selecting a topic, pre-writing, outlining, drafting, revising, editing and publishing. As argued by other researchers, "Good writers are produced by good writing classes [26]", because the product of writing requires students to go through several stepping stones $[16,25]$. Further, a teacher needs to give clear writing direction [18] and to create an engaging learning environment [3]; otherwise teachers and students may feel frustrated by language errors and a lack of improvement in students' writing [10].

By the end 2012, the COERRWP Evaluation indicated that students achieved various outcomes and formed differing opinions on the effects of the COERRWP. Some students said the COERRWP was useful in enhancing their writing performance and achieving a better grade, while other students indicated that the COERRWP was not very effective and even boring since it required many steps before students could complete the required writing activities. The different results achieved from the writing tests by students at the Centre may be indicative of various impact factors, for instance, the poor planning and inconsistent teaching activities, the lack of writing resources, and the insufficient writing time.

This difference hence needs to be further examined in order to ascertain what the most significant factors are influencing disparate outcomes achieved by the Cambodian students. For this purpose, the study was conducted; that is, in order to identify the impacts of the COERRWP on students' writing attitudes and performance. Also, the study attempts to assess whether there are any significant impacts of the COERRWP that correlate with the age, gender and/or language proficiency of Cambodian EFL students at the Centre.

\section{Literature Review}

\subsection{The COERRWP}

The COERRWP was designed as an extra writing lesson to the regular writing classes. A list of guided questions was 
designed by COERR teachers for students so that the students can use for revising and improving their writings in order to have positive results. Students were assigned to write a cause-effect, an argumentative, a comparative, and a problem-solution paragraph about various topics. The topics are, for example, the use of pesticides; the advantages and disadvantages of computers on children, and what constitutes a successful restaurant. Grades were assigned provided that the students completed all steps in the writing process. The timeframe was flexible so that the teachers could adjust the dates to complement their teaching activities for reading, correcting, and giving feedback for the students' writings [5]. Followings are the COERRWP's writing steps:

Table 1. The writing steps.

\section{Writing Process}

Selecting a topic guides students to choose the appropriate topic for writing. They can work in pairs or groups to generate ideas.

Prewriting gets students to do their writings through: listing (by brainstorming), freewriting, clustering or Journalists' questions (by asking questions). Students can exchange their prewriting and make comments following guided questions

Outlining gets the students to arrange the topic, topic sentence, and details/examples into a logical or chronological order [from less important to more important, from general to specific, from chronological order, from negative to positive, from causes to effects, from problems to solution etc.] The students exchange their outlines and use guided questions to improve their outlines.

Drafting gets the students to start their writings without worrying about spelling, punctuation, capitalization, and grammar. Students submit their first (rough) draft along with their prewriting, and outline. Teacher makes comments.

Revising gets the students to change their ideas and make their writings clearer, better, and more interesting. They can work in pair and group to improve their writings.

Editing \& Publishing gets students to polish the errors in grammar, spelling, punctuation, and capitalization. The students exchange their revised copies (second draft) and do peer-editing.

\subsection{English Writing Instruction in Cambodia}

English Writing Instruction is one of the core courses for the Cambodia's Higher Education Institute. Especially, the course has been offered to students in the degree of English education. For example, Institute of Foreign Languages (IFL) at the Royal University of Phnom Penh (RUPP) has offered the courses of Writing Skill I, II, III, IV and V for developing students' skills and competence in writing regarding paragraph and essay structures; article and book reviews; and citation and referencing [14]. Similar course syllabuses have been used by other universities in Cambodia, especially in Battambang. By and large, the Writing Course has not been intensively designed and taught in the general English program, let alone the COERR Language Skills Center. Therefore, most students tend to have poor writing skills since there is a lack of specific course offered to students in the general English program.

\subsection{English Writing Research in Cambodia}

The studies of writing in English in Cambodia have mostly been conducted in Phnom Penh, especially using participants selected from the Royal University of Phnom Penh (RUPP). For example, the researcher applied an action research to investigate social awareness through reading and writing. Another researcher employed a qualitative approach to examine writing self-efficacy (an ability to write in English), writing goal orientation (an expectation to write better English paragraph), and writing achievement of 244 Cambodian university students [1]. Another study was also conducted to focus on the trends and patterns of learning styles among 215 Cambodian students in the English Faculty at RUPP [13].

The literatures provide a fertile account of writing in English among Cambodian EFL students; however, student's attitudes and motivation of writing in English seems to be new phenomenon. In addition, several challenges have given rise to English language education, for example, the lack of an improved English Curriculum, the lack of learning facilities, the pay of teachers, and the lack of Cambodia's government decision to solve these problems [31]. Not only are these problems occurring in Phnom Penh, but these problems may also be challenging Cambodian EFL students at provincial levels such as Battambang. Therefore, there are seen as being worthwhile to carry out a study of the impact factors such as motivation, engagement and learning environment which are relatively new considerations for additional language researchers in Cambodia. That is, this study is especially conducted to investigate the correlative impacts of students' behaviour on the development of second language learning in Battambang province.

\subsection{Theories of Attitude and Performance in Writing}

The impetus of theories and models of attitudes into L2 writing research may be started around the 1980s [26], while the motivational theories of language learning can be noted from several works such as $[20,9,29]$. The other studies also provide important findings in relation to L2 writing and learner's attitudes, [7, 4] for example. The aforementioned authors have asserted that there is a correlation between ESL students' attitudes and their writing performance.

In addition, the literatures found a positive correlation between L2 attitudes and writing skills [12] while other asserted that the increase in student engagement and motivation in writing helps them improving their writing skills [19]. Further, applying peer feedback in the writing process helps students developing a positive attitude and improved writing skills [17]. These findings are similar to the study [15] pointed out that students' writing proficiency correlates with their attitudes.

Overall, literature indicates a significant benefit for research that evaluates an ESL / EFL student's attitudes towards their writing performance; however, this area of research is relatively new to Cambodia especially in 
Battambang province although English language education has been booming here for decades.

\section{Methodology}

\subsection{Participants}

The study was conducted in two stages. In the first stage, this study surveyed 45 students, selected from the intermediate level, upper level and an advanced level. The participants were taking the English course, used the Hemisphere Series [8]. Coupled with the Writing Project, students have been taught to write different essays, for instance, a problem-solution essay, a narrative experience essay, a process writing essay, a comparison-contrast essay, a definition essay, and a summary essay. The initial criteria of selection were based on achievement grades, for instance, above average, average, and below average. In the second stage, a quantitative survey was randomly administered to 80 students (35 students were selected and added to the initial cohort). More participants were randomly invited to participate in the study in order for generating strong reliability and validity of the results.

\subsection{Instruments and Data Collection}

The qualitatively in-depth study initially assessed 45 students, selected according to their achievement grades from the final exams through 2011, 2012, 2013 and 2014. The assessment of the written texts was based on the criteria; pre-writing, topic sentence, supporting details (content), conclusion, and lexico-grammar (structure and vocabulary). Writing scores from 2011 were considered the basis while scores in the following years were considered as progress scores. Control group was not included since the study was periodically conducted based on the researchers' experiences in teaching and applying the Writing Project. That is, the sampling technique was considered the limitation of the study.

Survey questionnaires were distributed to 80 students, randomly selected from the cohort of intermediate, upper and advanced levels. The questionnaires consist of two parts. Part A collects the respondent's background information i.e., sex, age, years of study, study level and occupation. Part B contains questions for assessing the impact of the Writing Project on the students' attitudes and their writing performance. Students were asked to rate the statements using a five-point Likert Scale, ranging from "strongly agree" to "strongly disagree."

\subsection{Data Analysis}

Data from writing score analyses and survey questionnaires were computerized into MS Excel and imported into the SPSS version 20. A descriptive statistics data tool was applied to see the mean scores and standard deviation from writing tests each year in correlation with ages, gender and English levels and to analyze data from survey questionnaire in order to see the frequency, percentage, crosstab (Chi-square test) and to understand the overall pattern of students' responses and the relationship between variables. The impact factors were interpreted and discussed based on the correlation of the writing scores, student's attitudes and performances manipulated by the project application. The changes in means and standard deviation of writing scores would represent a positive or negative impact of the project.

\section{Results of the Study}

The results were presented in three parts: respondents' profiles (age, gender, language proficiency, and educational level); the impact of the writing project on attitudes and writing performance of students; and the impact of COERRWP in correlation with age, gender, and language proficiency.

\subsection{Respondents' Profiles}

The results from the survey questionnaire showed that $52.6 \%$ of the respondents' ages were below $25 ; 25.6 \%$ others were under 20 years old; $9.0 \%$ of them were below 18 , and $12.8 \%$ were over 25 years old. This reflects that the majority of the enrolled students at the COERR language programs are adults; the majority $(71.8 \%)$ were studying at the university. This is in accordance with the Centre's admittance policy.

Moreover, more female students $(61.5 \%)$ than male $(38.5 \%)$ participated in the research study, and they have taken the English classes the Center. Further, $82.1 \%$ of the total respondents completed an English course over 4 years, and no students did an English course for less than one year. Due to the method used in the study, no difference in number of the respondents selected from the three cohorts participated in the study from each level.

\subsection{Research Question 1}

Are there any impacts of COERRWP on attitudes and writing performance of ESL / EFL learners?

Results from the analysis of writing scores in Table 2 indicate that the COERRWP has impacted students' actual writing performance. Comparing the progress scores in 2012, 2013 and 2014 with the baseline scores in 2011, for example, the advanced students improved their mean writing scores [7.95] from the baseline year 2011 to [10.10] in 2014, and the upper-level students' mean scores increased from [7.63] in 2011 to [10.78] in 2014. In contrast, the intermediate level students' mean scores in 2014 were reported below the mean score of baseline data in 2011, decreasing from [8.10] to [7.41]. The improvement of the mean scores of higher level students indicates that students with higher language proficiency tend to hold more positive attitudes to writing. Even though mean scores of students from the three levels in 2012 were lower than the mean scores of the baseline year 2011. 
Table 2. Comparing Mean Scores in the Writing Exam (2014, 2013, 2012, 2011).

\begin{tabular}{llllll}
\hline Years & & $\mathbf{2 0 1 4}$ & $\mathbf{2 0 1 3}$ & $\mathbf{2 0 1 2}$ & $\mathbf{2 0 1 1}$ \\
\hline & Mean & 10.1 & 7.9 & 7.9 & 7.9 \\
Advanced & N & 15 & 15 & 15 & 15 \\
Level & Std. Deviation & 1.26 & 2.85 & 2.94 & 2.17 \\
& Minimum & 8.50 & 4.00 & 2.50 & 4.50 \\
& Maximum & 12.00 & 13.50 & 13.75 & 12.00 \\
& Mean & 10.7 & 8.7 & 7.1 & 7.6 \\
Upper Level & N & 15 & 15 & 15 & 15 \\
students & Std. Deviation & 2.04 & 2.28 & 2.60 & 2.28 \\
& Minimum & 7.50 & 4.00 & 3.00 & 3.00 \\
& Maximum & 13.75 & 13.00 & 11.50 & 11.00 \\
& Mean & 7.4 & 9.1 & 5.2 & 8.1 \\
Intermediate & N & 15 & 15 & 15 & 15 \\
Level & Std. Deviation & 2.67 & 2.36 & 2.92 & 3.18 \\
& Minimum & 4.00 & 6.00 & 1.00 & 2.25 \\
& Maximum & 13.00 & 14.00 & 10.50 & 13.00 \\
& Mean & 9.4 & 8.6 & 6.7 & 7.8 \\
Total & N & 45 & 45 & 45 & 45 \\
& Std. Deviation & 2.50 & 2.50 & 2.98 & 2.53 \\
& Minimum & 4.00 & 4.00 & 1.00 & 2.25 \\
& Maximum & 13.75 & 14.00 & 13.75 & 13.00 \\
\hline
\end{tabular}

Additionally, results in Table 3 indicate that the COERRWP has been very effective in creating a positive attitude in students toward writing in English. The majority of students hold positive perceptions; for example, $73 \%$ of them responded optimistically that the COERRWP motivates them to do more writing in classes or elsewhere; $59 \%$ of them thought, through the project, they gain better understanding of the importance of writing skills; $77 \%$ of others like having their writings edited; $83 \%$ of the responses reflect that the editing guide helps improve grammar; and $66 \%$ agreed that the writing steps motivate their writing." These results demonstrate that the COERRWP has strongly impacted students to write in English. Especially, the findings seem to highlight that the guided questions appear to have provided students with the tools to write better since the combination of students" "strongly agree" and "agree" responses amounted to $83 \%$.

Further, students' writing performance seems to have been fostered through the application of COERRWP. The claims have been evidenced from the analysis that $73 \%$ of the respondents agreed that the COERRWP helps them reduce Khmer-English sentence styles; $88 \%$ of them agreed that the COERRWP enables them to use a variety of English sentence structures; $81 \%$ of them thought they are able to summarize and paraphrase, and more than $94 \%$ of the responses indicated that students are able to write better paragraphs, and $76 \%$ of others thought they have improved in essay writing. The students also thought the COERRWP helps them develop ideas for writing $(70 \%)$ and achieve good grades $(83 \%)$ (Table 4). However, the overall responses suggest the improvement of writing is at the macro performance (paragraph and essay) level rather than the micro performance. More specifically, the analyses have revealed that respondents have improved writing habits and skills, especially as pertaining to sentence structures, paragraphs and essays.

Table 3. The impacts of the writing project on students' attitudes.

\begin{tabular}{|c|c|c|c|c|c|}
\hline Statement $(\mathrm{n} 2=78)$ & Strongly agree & Agree & no idea & disagree & Strongly disagree \\
\hline $\begin{array}{l}\text { 1. The Writing Project has encouraged me to do more writing in classes } \\
\text { and elsewhere. }\end{array}$ & $22 \%$ & $53 \%$ & $24 \%$ & $1 \%$ & - \\
\hline $\begin{array}{l}\text { 2. The Writing Project made me realize that writing is essential skills to } \\
\text { master for both academics and career purposes }\end{array}$ & $13 \%$ & $46 \%$ & $40 \%$ & & $1 \%$ \\
\hline $\begin{array}{l}\text { 3. I dislike having my writing to be edited so I do not need to follow the } \\
\text { project. }\end{array}$ & & $3 \%$ & $20 \%$ & $62 \%$ & $15 \%$ \\
\hline 4. The activities of the project are difficult to follow. & $4 \%$ & $28 \%$ & $21 \%$ & $47 \%$ & \\
\hline $\begin{array}{l}\text { 5. I like to follow the guided questions because they help correct my } \\
\text { grammatical and spelling mistakes. }\end{array}$ & $9 \%$ & $74 \%$ & $11 \%$ & $5 \%$ & $1 \%$ \\
\hline 6. I feel the activities in each step of the project motivate me to write. & $6 \%$ & $60 \%$ & $28 \%$ & $5 \%$ & $1 \%$ \\
\hline 7. I don't need to follow each step in the project when I am writing. & $1 \%$ & & $14 \%$ & $63 \%$ & $22 \%$ \\
\hline
\end{tabular}

Table 4. The effects of the writing project on students' writing performance.

\begin{tabular}{|c|c|c|c|c|c|}
\hline Statements $(n=78)$ & strongly agree & Agree & no idea & disagree & strongly disagree \\
\hline 1. The project taught me to reduce Khmer sentence styles. & $22 \%$ & $51 \%$ & $15 \%$ & $10 \%$ & $1 \%$ \\
\hline 2. The project taught me to use different types of English sentences. & $15 \%$ & $73 \%$ & $8 \%$ & $4 \%$ & - \\
\hline $\begin{array}{l}\text { 3. The project taught me to summarize and paraphrase ideas from the } \\
\text { reading materials. }\end{array}$ & $18 \%$ & $63 \%$ & $17 \%$ & $3 \%$ & - \\
\hline 4. The project has guided me to write good paragraph. & $31 \%$ & $63 \%$ & $5 \%$ & $1 \%$ & - \\
\hline 5. The project taught me to write good essay. & $14 \%$ & $62 \%$ & $21 \%$ & $4 \%$ & - \\
\hline 6. The project helps me develop ideas to write several paragraph essays. & $14 \%$ & $56 \%$ & $23 \%$ & $5 \%$ & - \\
\hline 7. The project taught me the systematic process of writing. & $19 \%$ & $64 \%$ & $10 \%$ & $6 \%$ & - \\
\hline $\begin{array}{l}\text { 8. I don't have problems with writing since I follow the writing steps in the } \\
\text { project }\end{array}$ & $5 \%$ & $31 \%$ & $21 \%$ & $42 \%$ & $1 \%$ \\
\hline 9. I do more writing after I learned the writing process from the project. & $5 \%$ & $51 \%$ & $36 \%$ & $5 \%$ & $3 \%$ \\
\hline 10. The writing project helps me to get better grade. & $10 \%$ & $73 \%$ & $14 \%$ & $3 \%$ & - \\
\hline
\end{tabular}




\subsection{Research Question 2}

Are there significantly different impacts of COERRWP on students in correlation with age, gender and level of language proficiency?

The analysis of writing scores of 45 students has revealed that students have positively improved their attitudes towards writing in English, yet the study has suggested a slight difference in mean scores of female students. There could be various reasons of gender differences in writing performance. For example, this could be because female students are more participatory, or due to teachers' anecdotal accounts of performance when undertaking the writing class with mixed genders. As illustrated by Table 5 in the baseline year, the male students' mean scores were higher than female students, [8.43] vs [7.50]; in contrast, mean scores of female students gradually increased from [8.24] in 2013 to [9.63] in 2014. This reflects the change of attitudes and performance female students pertaining to English language skills, especially writing. The issue of gender differences might suggest questions for further study, in particular as regards writing in English in Cambodian context.

The writing performance of students was also assessed by mean score according to criteria: (a) pre-writing (2 marks), (b) topic sentence ( 2 marks), (c) introduction with a thesis statement (2 marks), (d) paragraph content (6 marks), (e) concluding sentence / paragraph (1 mark), and (f) layout (1 mark). Comparing the mean scores for these criteria, they can be seen to be above average-[1.32] for pre-writing, [1.30] for topic sentence, [3.50] for content, [0.75] for organization, [0.63] for concluding and [1.47] for thesis statement.

The results of assessing scores by these criteria revealed that students' grades are above average except the mean scores for lexico-grammar and referencing. For example, the mean score of cause and effect connectors appears to be below average at [0.13], and the mean scores in using metaphors are also lower than the average at $[0.40]$. These figures mean that the knowledge and/or the accurate use of sentence structure are still limited among advanced level students. In short, there is no overall pattern regarding the positive results toward writing performance on each test item, but the remaining mean scores suggest that students tend to do better writing with regard to paragraph or essay structure rather than in detailed application of linguistic accuracy in their actual writing performance.

Table 5. Comparing mean scores between male and female students.

\begin{tabular}{|c|c|c|c|c|c|}
\hline Sex & & 2014 & 2013 & 2012 & 2011 \\
\hline \multirow{5}{*}{ Female } & Mean & 9.6 & 8.2 & 6.4 & 7.5 \\
\hline & $\mathrm{N}$ & 26 & 26 & 26 & 26 \\
\hline & Std. Deviation & 2.17 & 2.68 & 2.94 & 2.55 \\
\hline & Minimum & 4 & 4 & 2 & 2.25 \\
\hline & Maximum & 13 & 14 & 13.75 & 12.75 \\
\hline \multirow{5}{*}{ Male } & Mean & 9.15 & 9.13 & 7.19 & 8.43 \\
\hline & $\mathrm{N}$ & 19 & 19 & 19 & 19 \\
\hline & Std. Deviation & 2.94 & 2.2 & 3.06 & 2.47 \\
\hline & Minimum & 4.5 & 6 & 1 & 4.5 \\
\hline & Maximum & 13.75 & 13.5 & 12 & 13 \\
\hline \multirow{5}{*}{ Total } & Mean & 9.43 & 8.61 & 6.77 & 7.89 \\
\hline & $\mathrm{N}$ & 45 & 45 & 45 & 45 \\
\hline & Std. Deviation & 2.5 & 2.5 & 2.98 & 2.53 \\
\hline & Minimum & 4 & 4 & 1 & 2.25 \\
\hline & Maximum & 13.75 & 14 & 13.75 & 13 \\
\hline \multirow[t]{3}{*}{ Sex } & & 2014 & 2013 & 2012 & 2011 \\
\hline & Mean & 9.6 & 8.2 & 6.4 & 7.5 \\
\hline & $\mathrm{N}$ & 26 & 26 & 26 & 26 \\
\hline \multirow[t]{5}{*}{ Female } & Std. Deviation & 2.17 & 2.68 & 2.94 & 2.55 \\
\hline & Minimum & 4 & 4 & 2 & 2.25 \\
\hline & Maximum & 13 & 14 & 13.75 & 12.75 \\
\hline & Mean & 9.15 & 9.13 & 7.19 & 8.43 \\
\hline & $\mathrm{N}$ & 19 & 19 & 19 & 19 \\
\hline \multirow[t]{5}{*}{ Male } & Std. Deviation & 2.94 & 2.2 & 3.06 & 2.47 \\
\hline & Minimum & 4.5 & 6 & 1 & 4.5 \\
\hline & Maximum & 13.75 & 13.5 & 12 & 13 \\
\hline & Mean & 9.43 & 8.61 & 6.77 & 7.89 \\
\hline & $\mathrm{N}$ & 45 & 45 & 45 & 45 \\
\hline \multirow[t]{3}{*}{ Total } & Std. Deviation & 2.5 & 2.5 & 2.98 & 2.53 \\
\hline & Minimum & 4 & 4 & 1 & 2.25 \\
\hline & Maximum & 13.75 & 14 & 13.75 & 13 \\
\hline
\end{tabular}

Table 6. Different impacts according to age, gender and level of proficiency.

\begin{tabular}{|c|c|c|c|}
\hline \multirow{2}{*}{ Statements $(\mathrm{n} 2=78)$} & \multicolumn{3}{|c|}{ Chi-Square Test SIG. } \\
\hline & Age & Gender & LoP \\
\hline 1. The Writing Project has encouraged me to do more writing in classes and elsewhere. & $0.899^{\mathrm{ns}}$ & $0.916^{\mathrm{ns}}$ & $0.244^{\mathrm{ns}}$ \\
\hline $\begin{array}{l}\text { 2. The Writing Project made me realize that writing is essential skills to master for both academics and career } \\
\text { purposes }\end{array}$ & $0.250^{\mathrm{ns}}$ & $0.764^{\mathrm{ns}}$ & $0.044^{*}$ \\
\hline 3. I dislike having my writing to be edited so I do not need to follow the writing steps. & $0.290^{\mathrm{ns}}$ & $0.724^{\mathrm{ns}}$ & $0.091^{\mathrm{ns}}$ \\
\hline 4. The activities of the project are difficult to follow. & $0.137^{\mathrm{ns}}$ & $0.702^{\text {ns }}$ & $0.295^{\mathrm{ns}}$ \\
\hline 5. I like to follow the guided questions because it helps correct my grammatical and spelling mistakes. & $0.480^{\mathrm{ns}}$ & $0.638^{\mathrm{ns}}$ & $0.165^{\text {ns }}$ \\
\hline 6. I feel the activities in each step of the project motivate me to write. & $0.193^{\mathrm{ns}}$ & $0.426^{\mathrm{ns}}$ & $0.031^{*}$ \\
\hline 7. I do not need to follow each step in the project when I am writing. & $0.330^{\mathrm{ns}}$ & $0.421^{\mathrm{ns}}$ & $0.016^{*}$ \\
\hline 8. The project taught me to reduce Khmer sentence styles. & $0.617^{\text {ns }}$ & $0.750^{\text {ns }}$ & $0.149^{\text {ns }}$ \\
\hline 9. The project taught me to use different types of English sentences. & $0.675^{\text {ns }}$ & $0.433^{\text {ns }}$ & $0.231^{\mathrm{ns}}$ \\
\hline 10. The project taught me to summarize and paraphrase ideas from the reading materials. & $0.390^{\mathrm{ns}}$ & $0.519^{\text {ns }}$ & $0.178^{\mathrm{ns}}$ \\
\hline 11. The project has guided me to write good paragraph. & $0.594^{\mathrm{ns}}$ & $0.247^{\mathrm{ns}}$ & $0.856^{\mathrm{ns}}$ \\
\hline
\end{tabular}




\begin{tabular}{|c|c|c|c|}
\hline \multirow{2}{*}{ Statements $(\mathrm{n} 2=78)$} & \multicolumn{3}{|c|}{ Chi-Square Test SIG. } \\
\hline & Age & Gender & LoP \\
\hline 12. The project taught me to write good essay. & $0.024^{*}$ & $0.407^{\text {ns }}$ & $0.173^{\text {ns }}$ \\
\hline 13. The project helps me develop ideas to write several paragraph essays. & $0.001^{*}$ & $0.421^{\mathrm{ns}}$ & $0.735^{\mathrm{ns}}$ \\
\hline 14. The project taught me the systematic process of writing. & $0.106^{\mathrm{ns}}$ & $0.338^{\text {ns }}$ & $0.217^{\mathrm{ns}}$ \\
\hline 15. I don't have problems with writing since I follow the writing steps in the project & $0.227^{\mathrm{ns}}$ & $0.429^{\text {ns }}$ & $0.453^{\text {ns }}$ \\
\hline 16. I do more writing after I learned the writing process from the project. & $0.050^{*}$ & $0.158^{\mathrm{ns}}$ & $0.176^{\text {ns }}$ \\
\hline 17. The writing project helps me to get better grade. & $0.988^{\text {ns }}$ & $0.873^{\text {ns }}$ & $0.226^{\mathrm{ns}}$ \\
\hline
\end{tabular}

Ns. $=$ non-significant; $\mathrm{p}^{*}=<0.05$ (at significant)

In correlation with age, the reports from the Chi-Square Test (Table 6) indicate that nearly all p-values are greater than 0.05 , apart from the reports on the following statements whose p-values are less than 0.05 and hence, these are statistically significant results.

I feel that the activities set in each writing step motivate me. $(p=0.024 *<0.05)$

The writing project made me understand the importance of the writing process. $(p=0.001 * 0.05)$

The writing project helps me to get better grades from the writing tests.

$(p=0.050 * *<0.05)$

These results imply that the significant effect of the COERWP correlates with the age of students as well as encouraging them to write, guiding them to better understand the importance of writing and to achieve better scores. However, results from Chi-Square indicate no statistically significant effects between the Writing Project and gender were generated since all P-values of all statements related are greater than 0.05 . In contrast, the Chi-square test reports statistically significant effects in correlation between the COERRWP and language level as represented by the following statements:

The project taught me to reduce Khmer sentence styles ( $p$ $=0.044 *<0.05)$.

The writing project made me realize that writing is an essential skill to master for both in academia and career purposes $(p=0.031 * 0.05)$.

The project has guided me to write better essays $\left(p=0.016^{*}<0.05\right)$.

These results reveal that students who study at a higher level are able to see the correlative impacts of the COERRWP on their academic studies and careers. Hence, they feel that the project is really useful for them. Most importantly, the results imply that students who study higher language levels have clear purposes for academia and employment. Therefore, the project has had a positive effect on the development of language proficiency in that students feel it has scaffolded them through the necessary steps that will enable them to write better essays in English. However, significant effects could only be ascertained for items correlated with age and language, not gender.

\section{Discussion}

This study reveals that the COERRWP has been effective in fostering positive attitudes of students to write in English because it was structurally designed with series of mini lessons to help students gain confidence in applying the writing steps for their writings. As commended by scholars, "writing skill has correlated with the development or maintenance of positive attitudes of students [12]," through "an integrated learning context, motivation and language achievement [11]," with "a course-specific design relevant to the learner's interest, expectancy and satisfaction [10]".

However, students' actual performance in accuracy, lexicogrammar and citation remained below average as indicated in Table 4. This is perhaps the COERRWP design is best suited and aimed at improving the overall (macro) writing performance rather than micro performance or detailed accuracy. The low performance on these items might partly account for the strong influence of Khmer language structures. As highlighted by the literatures, Chinese students' writing can decline in language accuracy due to direct / inappropriate translation from Chinese to English and a lack of confidence among students in peer-editing [19, 22].

On the other hand, the impact of COERRWP appears to significantly correlate with age and language levels, not gender, although the mean scores of female students tend to improve more in their writing (Table 6). As indicated by previous studies, boys have far less interest in writing than girls [23]; hence, boys have lower performance indicators in writing as well as reading [6].

Moreover, an unexpected result has been revealed from this study that student's attitudes and performance relates to "the educational context, a term proposed by Gardner [11]" or "an external connection suggested by Schmidt [29]" that both terms are used to define variables that correlate learner's need and the components of education system, including the quality of the program and the profession and skills of the teacher, the teaching and learning materials, the curriculum, the learning environment, etc." This claim was supported by Tweed and Som [31], who reasserted, "English language has become a core subject for the Cambodian students since English knowledge is regarded one of the key employability in the ASEAN region." Therefore, the application of COERRWP seems to have coincided with the current situation, enhancing students' interest in English writing in light of the strong connections with local and regional contexts.

However, poor performance in lexico-grammar among Cambodian students in writing may reflect the weakness of COERRWP components and/or the feedback from teachers although the guided questions, particularly the revising and 
editing part, were designed to improve students' language accuracy. Also, the lack of opportunities for Cambodian students to express ideas through writing in English in social life may be one of the impact factors on their English skills. As supported by Chan [2], writing motivation may be increased when students choose to write their own topics about real-life problems. This indicates that English education in Battambang province lacks "sociability, a term associated with Schmidt, [29]" or "a target language community in Norton and Gao, [24]", which has been considered the the factor to arouse "students' motivation, and the one possible way to enhance students' motivation in writing [30]".

\section{Conclusions}

In conclusion, the COERRWP has positive impacts on students' attitudes and writing improvement with regards to macro or overall writing performance. First, the COERRWP has made students gradually improve their writing performance and increase their writing scores through four years, from 2011 to 214 . Second, the impact of COERRWP has motivated students to write better paragraph and essay structures and other macro writing performance indicators such as being able to do pre-writing, topic sentences, provide supporting details, organize, and construct a thesis statement. Third, the COERRWP has significantly impacted student's attitudes and performance in correlation with ages and language level since the senior students with higher level tend to receive better scores. Therefore, the project has sparked students' interest in studying writing, using peerediting, and developing language proficiency so that they feel confident in writing in the target language (English) and upgrading their writing skills.

\section{Recommendations}

Although the COERRWP has positively impacted students' attitudes and their writing performance, the COERRWP components and teaching process should be modified to increase individual student's participation in writing. First, teachers should invest more time especially with the poor writer. By doing so, teacher can increase student's motivation and performance in language accuracy. Individual feedback may also help students feel less anxiety in writing. The COERRWP could extend the writing activities beyond classroom settings; for example, by including a writing competition or writing clubs so students become more socially situated to writing in English.

Further professional development such as weekly or monthly writing courses should also be undertaken to strengthen the quality of teachers and their teaching that they might be better able to effectively employ the COERRWP in classes, thereby enabling students to construct better English sentence structures and improve student's lexico-grammar in writings.

\section{Limitations}

The reliability of writing scores obtained from the Center and sampling method can be considered the limitations for this study. Technically, a larger sample size should be employed for the study to generate more reliable and valid findings in order for generating statistically significant results. However, the study focuses on the case of the COERR Language Skills Center. The later studies should include control and free control group, and the assessment of writing should be designed with checklist or essay assessment scales to ensure the reliability and consistency of the results.

Further studies using other methodologies including mixed methods and/or qualitative or action research might also generate different findings or corroborate these findings. The future studies should also be conducted to include larger populations such as teachers, students and school administers. This inclusion may generate more reliable and valid results. Therefore, the relationship between students' attitudes and writing skills needs to be further investigated by other researchers, in similar contexts, using different methods to ensure reliability and make it possible to generalize these findings.

\section{Acknowledgements}

We wish to gratefully thank to Dr. Judie Cross for her wholehearted assistance in guiding and mentoring us.

\section{References}

[1] Chea, S., \& Shumow, L, "The relationships among writing self-efficacy, writing goal orientation, and writing achievement," Language Education in Asia, 5(2), pp. 253-269, 2014.

[2] Chan, V, "Integrating social awareness through reading and writing: A classroom action research," Language Education in Asia, 5(2), pp. 216-227, 2014.

[3] Cheng, H-F., \& Dörnyei, Z, "The Use of Motivational Strategies in Language Instruction: The Case of EFL Teaching in Taiwan," Innovation in Language Learning and Teaching 1(1), pp. 153-174, 2007.

[4] Ching-Chun, S., \& Gamon, J., "Web-based learning: Relationships among student motivation, attitude, learning styles, and achievement," Journal of Agricultural Education, 42 (4), pp. 12-20, 2001.

[5] COERR, "Writing Project," Battambang, Cambodia, 2012.

[6] Collins, C., Kenway, J., \& Mcleod, J., "Factors influencing the educational performance of males and females in school and their initial destinations after leaving school," Department of Education, Training and Youth Affairs. Canberra, AGPS, 2000.

[7] Coulmas, F., "Writing system: An introduction to their linguistic analysis," UK: Cambridge University Press, 2003.

[8] Diana Ren and Susan Iannuzzi, "Hemispere Series 4," McGraw Hill Company, USA, 2008. 
[9] Dörnyei, Z., "Motivation in second and foreign language learning," Language Teaching, 31(3), pp. 117-135, 1998.

[10] Dörnyei, Z. "The Psychology of the Language Learner: Individual Differences in Second Language Acquisition," New Jersey: Lawrence Erlbaum Associates, Inc, 2005.

[11] Gardner, R. C., "Motivation and second language acquisition," PORTA LINGUARUM, 8, pp. 9-20, 2007.

[12] Hashemian, M., \& Heidari, A., "The relationship between L2 learners' motivation/attitude and success in L2 writing," Procedia - Social and Behavioral Sciences, 70, pp. 476-489, 2013.

[13] Heng, K. "College student involvement in English language learning in Cambodia: Trends and patterns," Journal of International Development and Cooperation, 19(1), pp.13-23, 2012.

[14] http://www.rupp.edu.kh/ifl/english

[15] Jahin, J. H. "The effect of peer reviewing on writing apprehension and essay writing ability of prospective EFL teachers," Australian Journal of Teacher Education, 37(11), pp. 60-84, 2012.

[16] Krashen, S "The Composing Process," Research Journal: Ecolint Institute of Teaching and Learning. International School of Geneva. vol 2, pp. 20-30, 2014.

[17] Kulprasit, W., \& Chiramanee, T., "Boosting EFL students' positive attitudes toward writing in English: The role of journal writing with peer feedback," ABAC Journal, 32(3), pp. 20-28, 2012.

[18] Langan, J., "English Skills (9th ed.)" New York: McGraw Hill Higher Education, 2007.

[19] Lo, J., \& Hyland, F., Enhancing students' engagement and motivation in writing: The case of primary students in Hong Kong," Journal of Second Language Writing, 16, pp. 219-237, 2007.

[20] Masgoret, A. M., \& Gardner, R. C., "Attitudes, motivation and second language learning: A meta-analysis studies conducted by Gardner and Associates" Language Learning, 53(S1), p. 167-210, 2003.

[21] McCarthey, S., \& Mkhize, D., "Teachers' Orientation Towards Writing," Journal of Writing Research, 3(1), pp. 1-33, 2013.

[22] Morgan, B., Fuisting, B., \& White, J., "University student attitudes towards peer review in EFL writing: A quantitative study," Language Education in Asia, 5(1), pp. 93-116, 2014.

[23] Murisuo-Storm, T., "Girls and boys like to read and write different texts," Scandinavian Journal of Educational Research, 50(2), pp. 111-125, 2006.

[24] Norton, B., \& Gao, Y., "Identity, investment, and Chinese learners of English," Journal of Asian Pacific Communication, 18(1), pp. 109-120, 2008. [25] Oshima, A., \& Hougue, A., "Introduction to Academic Writing (3 ed.)," New York, NY: Pearson Education Inc., 2006.

[25] Petric, B., "Students' attitudes towards writing and the development of academic writing skills," The Writing Center Journal, 22(2), pp. 9-27, 2002.

[26] Raimes, A., "Keys for Writers (4th Ed.)," Boston: Hougton Muffin Company, 2005.

[27] Sally Barr Ebest, Alred, G., Brusaw, T. C., \& Oliu, E. W., "Writing from A to Z: The Eassy-to-use Reference Handbook," New York, NY: McGraw Hill, 2004.

[28] Schmidt, R., Boraie, D., \& Kassabgy, O., "Foreign language motivation: Internal structure and external connections," In R. Oxford (Ed.), Language learning motivation: Pathways to the new century. Honolulu, Hawaii: University of Hawaii, 1996.

[29] Troia, G. A., Shankland, R. K., \& Wolbers, K. A., "Motivation research in writing: Theoretical and empirical considerations," Reading \& Writing Quarterly: Overcoming Learning Difficulties, 28(1), pp. 5-28, 2012.

[30] Tweed, D. A., \& Som, M., "English language education in Cambodia and international support ahead of ASEAN integration," In R. Stroupe \& K. Kimura (Eds.), ASEAN integration and the role of English language teaching. Phnom Penh, Cambodia: IDP Education Cambodia, 2015. 